\title{
Paper-based Microfluidic Immunoassay for Electrochemical Detection of B-type Natriuretic Peptide
}

\author{
Yong Zheng ${ }^{1}$, Zhen Huang ${ }^{1}$ and Jidong Zhang ${ }^{2, *}$ \\ ${ }^{1}$ Department of Cardiovascular Surgery, Affiliated Hospital of Taishan Medical University, Taian, \\ Shandong, 271000, P.R. China \\ ${ }^{2}$ Department of Cardiology, Affiliated Hospital of Qingdao University, Qingdao, Shandong, 266003, \\ P.R. China \\ *E-mail: jidongzhangwuli@ sina.com
}

doi: $10.20964 / 2018.03 .78$

Received: 4 October 2017 / Accepted: 12 November 2017 / Published: 5 June 2018

\begin{abstract}
Heart failure has been acknowledged as a common disorder that leads to great morbidity and mortality. In heart failure and other cardiovascular disorders, effective biomarkers include cardiac natriuretic peptides, among which the most prominent one is B-type natriuretic peptide (BNP). The present study proposed the fabrication of a screen-printed working electrode (SPWE), with which a label-free and highly sensitive paper-based electrochemical immunosensor was successfully prepared. In addition, the SPWE was modified by amino functional graphene $\left(\mathrm{NH}_{2}-\mathrm{G}\right) /$ thionine (Thi)/gold nanoparticles (AuNPs) nanocomposites, which led to the immobilization of anti-BNP and an enhancement in the determination sensitivity. The linear range and limit of detection (LOD) were determined to be 0.05 to $30 \mathrm{ng} / \mathrm{mL}$ and $0.012 \mathrm{ng} / \mathrm{mL}$, with a corresponding correlation coefficient of 0.996 .
\end{abstract}

Keywords: B-type natriuretic peptide; Microfluidic system; Electrochemical detection; Immunoassay; Congestive heart failure

\section{FULL TEXT}

(C) 2018 The Authors. Published by ESG (www.electrochemsci.org). This article is an open access article distributed under the terms and conditions of the Creative Commons Attribution license (http://creativecommons.org/licenses/by/4.0/). 